\title{
Pancreatic Gastrin Stimulates Islet Differentiation of Transforming Growth Factor $\alpha$-induced Ductular Precursor Cells
}

\author{
Timothy C. Wang, * Susan Bonner-Weir, ${ }^{\star}$ Phillip S. Oates, ${ }^{\star}$ MaryBeth Chulak, " Babette Simon, \\ Glenn T. Merlino," Emmett V. Schmidt," and Stephen J. Brand* \\ ${ }^{*}$ Gastrointestinal Unit, Department of Medicine, Massachusetts General Hospital, Boston, Massachusetts 02114; ${ }^{\ddagger}$ Joslin Research \\ Laboratory, Joslin Diabetes Center, Boston, Massachusetts 02215; ${ }^{\S}$ Laboratory of Molecular Biology, National Cancer Institute, \\ National Institutes of Health, Bethesda, Maryland 20892; and "Massachusetts General Hospital Cancer Center, \\ Charlestown, Massachusetts 02129
}

\begin{abstract}
Gastrin is transiently expressed in fetal islets during a critical period of their development from protodifferentiated islet precursors in fetal pancreatic ducts. To examine the possible role of gastrin as an islet cell growth factor, postnatal islet growth was studied in transgenic mice which overexpress gastrin and TGF $\alpha$ in their pancreas. Overexpression of a TGF $\alpha$ transgene causes metaplastic ductules containing numerous insulin expressing cells that resemble protodifferentiated precursors of the fetal pancreas. However, islet mass of the TGF $\alpha$ transgenic mice was not increased. Pancreatic overexpression of gastrin from a chimeric insulin/gastrin transgene transcribed from the insulin promoter markedly decreased the TGF $\alpha$-stimulated increase in pancreatic duct mass. Furthermore, pancreatic coexpression of both gastrin and TGF $\alpha$ significantly increased islet mass in mice expressing both transgenes. These findings indicate that TGF $\alpha$ and gastrin can act synergistically to stimulate islet growth, although neither peptide alone is sufficient. Islet growth may possibly be stimulated through gastrin promoting the differentiation of insulin-positive cells in the TGF $\alpha$-induced metaplastic ducts. This transgenic study suggests that islet neogenesis can be reactivated in the ductular epithelium of the adult pancreas by local expression of two growth factors, gastrin and TGF $\alpha$. (J. Clin. Invest. 1993. 92:1349-1356.) Key words: pancreatic ducts $\bullet$ islets $\bullet$ gastrin • transforming growth factor $\alpha$

\section{Introduction}

The pancreatic islets develop from endodermal stem cells that lie in the fetal ductular pancreatic epithelia, which also contains stem cells that develop into the exocrine pancreas $(1,2)$. Islet development proceeds through discrete developmental states during fetal gestation, punctuated by dramatic transitions. The initial period is a protodifferentiated state which is characterized by the commitment of these pluripotent stem cells to the islet cell lineage, manifested by the expression of insulin and glucagon. These protodifferentiated cells comprise a population of committed islet precursor cells which express only low levels of islet specific gene products and lack the cytodifferentiation of mature islet cells (1). Around day 16 in

Address correspondence to Stephen J. Brand, M. D., Ph. D., Gastrointestinal Unit, Department of Medicine, Massachusetts General Hospital, Fruit Street, Boston, MA 02114.

Received for publication 4 January 1993 and in revised form 27 April 1993.

The Journal of Clinical Investigation, Inc.

Volume 92, September 1993, 1349-1356 mouse gestation, the protodifferentiated pancreas begins a phase of rapid growth and differentiation characterized by cytodifferentiation of islet cells and a several hundredfold increase in islet specific gene expression. Histologically, islet formation (neogenesis) becomes apparent as proliferating islets budding from the pancreatic ducts. In the weeks after birth the rate of islet growth slows, with islet neogenesis becoming much less apparent. The islets also attain a fully differentiated state with maximal levels of insulin gene expression. Similar to many organs, the differentiated adult pancreas has reduced regenerative potential and low levels of cell turnover, in contrast to the rapid proliferation seen in fetal development.

As in many tissues, synergistic interactions between combinations of growth factors probably regulate pancreatic growth and development (3). Although studies of fetal explants have identified important mesenchymal factors which stimulated pancreatic differentiation, these growth factors have not been purified or structurally characterized (4). Some known regulatory peptides have also been shown to stimulate pancreatic growth and differentiation. EGF is a potent stimulus of ductular cell proliferation ( 5 ). Furthermore, both EGF and its homologue TGF $\alpha$ are expressed in pancreatic duct and acinar cells, and EGF receptors are found on acinar cells and the apical surface of duct cells (6). Overexpression of TGF $\alpha$, EGF, and EGF receptor levels have been demonstrated in pancreatic duct neoplasms, supporting their role in stimulating pancreatic proliferation. Transgenic overexpression of TGF $\alpha$ has distinctive effects on the pancreas which differ from other digestive organs $(7,8)$. Overexpression of TGF $\alpha$ in the liver and intestines causes hyperplasia. By contrast, TGF $\alpha$ overexpression in the mouse pancreas results in ductular hyperplasia and pronounced interstitial fibrosis, without increasing the acinar cell mass (9). TGF $\alpha$ overexpression also induces metaplastic changes in the ductules manifest by the expression of amylase, an acinar cell-specific product (8). Numerous ducts cells have mixture of zymogen and mucin granules, suggesting that TGF $\alpha$ expression induces metaplasia of acinar cells into duct like cells (9). Thus, TGF $\alpha$ overexpression alters pancreatic differentiation by disturbing the normal balance between TGF $\alpha$ and other growth factors $(7,8)$.

Another peptide known to regulate pancreatic growth is cholecystokinin (CCK), ${ }^{1}$ a gastrointestinal peptide hormone. CCK stimulates proliferation of pancreatic acinar cell in vivo and in vitro (10-12). Nevertheless, it is unlikely that CCK regulates pancreatic growth during fetal development since the levels of CCK peptide expressed in fetal life are negligible (13).

1. Abbreviations used in this paper: CCK, cholecystokinin; INSGAS, insulin/gastrin. 
However, gastrin, the homologue of CCK, is transiently expressed in the islets of the developing pancreas (13). In the adult, gastrin acts as a gastric hormone regulating acid secretion, and consequently the major site of gastrin expression is the stomach. In the fetus, however, the main site of gastrin expression is the pancreatic islets (13). Although the role of pancreatic gastrin in islet development is undefined, some clinical observations suggest gastrin may influence islet growth. Hypergastrinemia, caused by gastrin-expressing islet cell tumors and atrophic gastritis, is associated with nesidioblastosis, which is characterized histologically by islet cells budding from pancreatic ducts similar to that seen during in fetal islet development $(14,15)$. An abnormal persistence of pancreatic gastrin has also been documented in a case of infantile nesidioblastosis (16). However, in neither circumstance was a causal relationship established between the nesidioblastosis and gastrin stimulation. Therefore, to elucidate the role of pancreatic gastrin expression in islet development, we report studies on the transgenic overexpression of TGF $\alpha$ and gastrin in the pancreas, which suggest that TGF $\alpha$ and gastrin regulate sequential stages of islet development.

\section{Methods}

\section{Animals}

FVB/N mice were obtained from Taconic Farms Inc. (Germantown, NY), and CD1 mice were obtained from Charles River Laboratories, Wilmington, MA. The TGF $\alpha$ transgenic line (MT42) used in this study, which expresses high levels of TGF $\alpha$ from a mouse metallothionein 1 promoter, was described by Jhappan et al. (7).

\section{Insulin/gastrin (INSGAS) transgene construct}

A PvuII-Rsal fragment encompassing nucleotides -370 to +38 of the rat insulin I gene (17) was ligated into pGem 1 (Promega Corp., Madison, WI). A 4.4-kb Bam HI-EcoRI fragment containing the 1.5-kb intron 1 and exons 2 and 3 of the human gastrin gene, which encodes the preprogastrin peptide precursor $(18,19)$, was isolated and subcloned downstream of the rat insulin I fragment in pGem 1 (Promega). The insulin-gastrin fusion gene was excised as a $4.8-\mathrm{kb}$ XbaI-EcoRI fragment.

\section{Generation and characteri:ation of transgenic mice}

The microinjection fragment was isolated by agarose gel electrophoresis, purified by $\mathrm{CsCl}$ gradient purification, and dialyzed extensively against injection buffer ( $5 \mathrm{mM} \mathrm{NaCl}$; $0.1 \mathrm{mM}$ EDTA; $5 \mathrm{mM}$ Tris- $\mathrm{HCl}$ $\mathrm{pH}$ 7.4). Fertilized oocytes from FVB/N inbred mice (Taconic Farms) at the single cell stage were microinjected using standard techniques (20). Surviving embryos were then implanted into the oviducts of CD1 (Charles River Laboratories) foster mothers according to published procedures (20). Transgenic founder mice were identified by DNA blot techniques using DNA isolated from individual mouse tails, and a human gastrin exon II probe labeled with $\left[{ }^{32} \mathrm{P}\right] \mathrm{dCTP}$ by random priming. F1 mice and their siblings were similarly identified.

Homozygous MT42 mice containing the MT-TGF $\alpha$ transgene derived from a CD-1 mouse strain (7) were crossed with heterozygous INSGAS mice. Mating the homozygous MT-TGF $\alpha$ (MT-42) mice ( TGF $\alpha$ ) with heterozygous INSGAS mice gave offspring that were either heterozygous single transgenic (TGF $\alpha$ ) or double transgenic containing both INSGAS and TGF $\alpha$ transgenes (INSGAS/TGF $\alpha$ ). Since INSGAS were FVB strain and TGF $\alpha$ were CD1 strain, TGF $\alpha$ homozygotes and CD1 controls were both mated with FVB to produce FVB/ $\mathrm{CD} 1$ strain background for all three groups of mice. After weaning, the offspring were placed on acidified $50 \mathrm{mM} \mathrm{ZnCl}$ as previously described to induce the metallothionein promoter ( 7$)$. Mice were treated with $50 \mathrm{mM} \mathrm{ZnCl}$ from $3 \mathrm{wk}$ until killing at age $17 \mathrm{wk}$.

\section{Northern blot hybridization assay}

For Northern analysis, total RNA was extracted from tissues by the method of Cathala et al. (21). Samples of $20 \mu \mathrm{g}$ of total RNA were resolved on a $1 \%$ agarose denaturing gel and transferred to nitrocellulose. RNA blots were hybridized with ${ }^{32} \mathrm{P}$-labeled TGF $\alpha$ riboprobes or exon II of human gastrin that did not cross-hybridize with endogenous mouse gastrin mRNA.

\section{Peptide radioimmunoassays}

Gastrin. Tissues were extracted and assayed for gastrin immunoreactivity by radioimmunoassay as described previously using antibody 2604 which is specific for biologically active $C$ terminally amidated gastrin, in a gastrin radioimmunoassay as previously described (22). Tyrosine monoiodinated human gastrin 17 tracer was used in all assays and synthetic human gastrin 17 was used as a standard.

$T G F \alpha$. Tissues were frozen in liquid nitrogen, ground to powder with mortar and pestle, and subjected to acid-ethanol extraction as described (23). Extracts were reconstituted with water, and protein concentrations determined with a Coomassie blue dye binding assay (Bio-Rad Laboratories, Richmond, CA). Aliquots from the pancreata were tested in duplicate in a TGF $\alpha$ radioimmunoassay, which measured competition with ${ }^{125}$ I TGF $\alpha$ for binding to a solid-phase rabbit antibody raised against the $\mathrm{COOH}$ terminus of rat TGF $\alpha$ (kit from BioTope, Seattle, WA).

\section{Histological analysis and immunohistochemistry}

The pancreas was removed, weighed, similarly oriented in cassettes, fixed in Bouin's solution, and embedded in paraffin. Routine 5- $\mu \mathrm{m}$ paraffin sections were stained with hematoxylin and eosin according to standard methods. Immunohistochemistry was performed on $5 \mu \mathrm{m}$ paraffin sections by the immunoperoxidase method (24), using a monoclonal antigastrin antibody or a guinea pig anti-human insulin antibody (Linco, Eureka, MO) (25). A preimmune guinea pig serum was used as a negative control.

The relative volume of islets, ducts, or interstitial cells was quantified from one random section from each animal, using the pointcounting method (26) as described by Bonner-Weir et al. (25). At least 2,000 points over tissue were counted as intercepts of a 50-point grid at a magnification of 170; the entire section was covered without overlap. Mass of ductules or islet was calculated by multiplying the relative volume and the animal's pancreatic weight. To normalize different mean body weights, the mass was expressed as micrograms per gram body weight.

\section{Results}

Previous transgenic studies have shown that local overexpression of TGF $\alpha$ disturbs normal pancreatic differentiation, causing extensive ductular metaplasia and interstitial fibrosis, in contrast to the hyperplasia seen in other epithelial tissues (7, 8 ). The TGF $\alpha$-induced metaplastic ducts show amylase immunoreactivity, indicating exocrine-specific gene expression in the pancreatic duct cells (8). In contrast, exocrine gene expression is rarely seen in pancreatic ducts of age-matched nontransgenic mice of the same strain. To examine whether TGF $\alpha$ overexpression also results in islet-specific gene expression in pancreatic ducts, pancreatic tissue from adult 4- and 9-mo-old MT-TGF $\alpha$ (MT-42) transgenic mice (7) were immunostained for insulin. Immunoperoxidase staining showed numerous insulin staining cells in the metaplastic ducts from the TGF $\alpha$ transgenic pancreas (Fig. 1), whereas insulin staining cells were virtually absent from the nontransgenic ducts. When at least 600 ductular cells/animal were scored at a final magnification of 400 , insulin-positive cells were seen at a frequency of $6.0 \pm 0.9 \%(n=5)$ in the metaplastic ductules of TGF $\alpha$ trans- 


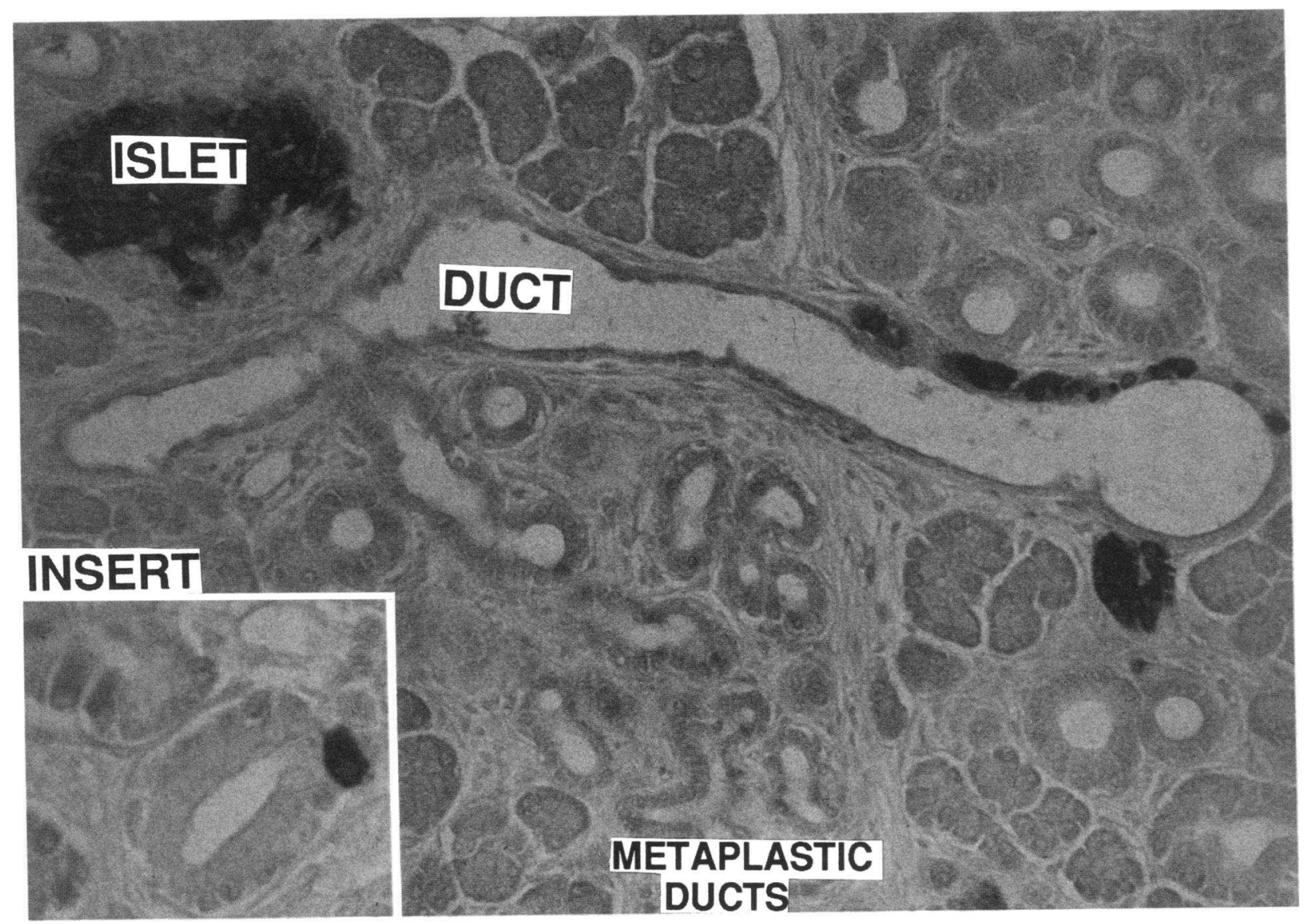

Figure 1. ( Top) Insulin-positive cells within TGF $\alpha$-induced metaplastic ductules from a 9-mo-old MT-42 TGF $\alpha$ transgenic mouse demonstrated using immunoperoxidase-staining guinea pig anti-human insulin sera. (Insert) High power magnification.

genic mice. Occasional ductular cells stained with the same intensity of insulin staining as the adjacent islets, but most had less intense staining (Fig. 1, insert). The low level of insulin staining of the ductular cells resembles the low levels of insulin gene expression postulated to occur in the protodifferentiated cells in the ducts of the developing pancreas $(1,27)$.

However, despite the increased number of insulin-positive cells in the metaplastic ducts, the islet mass of the TGF $\alpha$ transgenic mice was not increased. The islet mass as quantified by point counting morphometrics was $2.14 \mathrm{mg} \pm 0.84$ (mean $\pm \mathrm{SE}$, $n=5$ ) in the TGF $\alpha$ transgenic pancreas, compared to 1.93 $\mathrm{mg} \pm 0.46(n=6)$ in nontransgenic FVB/CD1 strain of mice of the same age similarly treated with zinc chloride. One interpretation of these findings is that TGF $\alpha$ overexpression causes proliferation of protodifferentiated precursors, but cannot alone effect the transition of these protodifferentiated cells into fully differentiated islets. Since differentiation of protodifferentiated islet precursors occurs during late fetal development, factors regulating this transition would likely be expressed in islets during this period. Among the factors expressed in the developing islets is the gastrointestinal peptide, gastrin.

To examine the possible role of gastrin in regulating islet differentiation, transgenic mice were created that express a chimeric INSGAS transgene. The INSGAS transgene contains exons 2 and 3 of the human gastrin gene, which encode the preprogastrin precursor under the transcriptional control of the insulin promoter, which directs $\beta$ islet cell specific expression (Fig. $2 A$ ). Unlike the gastrin gene, insulin gene expression is not switched off after birth. Thus, the INSGAS transgene results in a persistence of gastrin expression in the adult pancreas. Northern blots of RNA isolated from different tissues of 8-wkold INSGAS transgenic mice were hybridized with a human gastrin exon II probe. This probe is specific for the human gastrin gene; no hybridization was seen in antral RNA of INSGAS and nontransgenic FVB mice expressing high levels of murine gastrin mRNA. High levels of gastrin transgene mRNA were seen in the pancreas but not in any other tissues (data not shown). A radioimmunoassay of pancreatic extracts from INSGAS transgenic mice showed high levels of gastrin immunoreactivity that exceeded the gastrin content in the gastric antrum expressed from the endogenous murine gene (Fig. 2 $B)$. No gastrin immunoreactivity was detected in pancreatic extracts of nontransgenic adult control mice. The gastrin radioimmunoassay is specific for carboxy amidated precursors, indicating that the gastrin peptide precursor is efficiently processed after translation to the bioactive peptide. Immunohistochemistry with a gastrin monoclonal antibody showed that the gastrin transgene is expressed specifically in pancreatic beta cells (Fig. $2 C$ ).

Although the INSGAS transgenic mice had high levels of expression of gastrin in the postnatal pancreas (Fig. $2 \mathrm{~B}$ ), the INSGAS transgenic mice had pancreatic histology identical to controls. Islet mass as quantified by point-counting morphometrics (26) was identical in 5-6-wk-old INSGAS mice $(1.78 \pm 0.21 \mathrm{mg}, n=11)$ and age-matched nontransgenic controls $(1.74 \pm 0.19 \mathrm{mg}, n=11)$. Thus, sustained expression of 
A

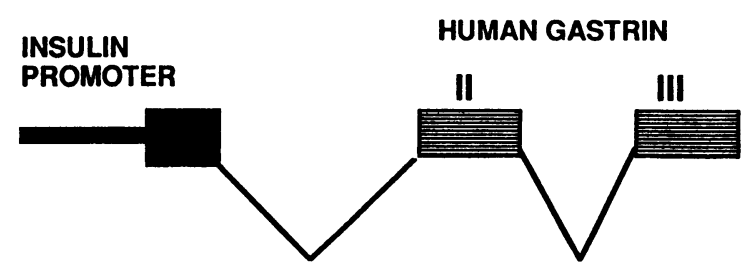

B

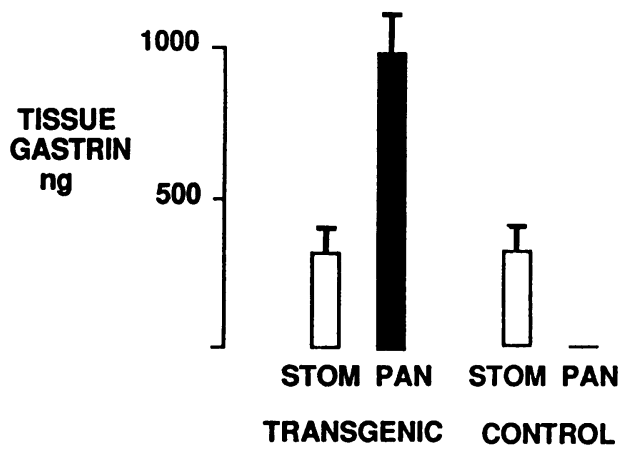

Figure 2. Pancreatic gastrin expression from a chimeric insulin-gastrin (INSGAS) transgene. $(A)$ The INSGAS transgene comprised $370 \mathrm{bp}$ of $5^{\prime}$ flanking DNA and the first noncoding exon of the rat insulin I gene (17) ligated to a BamHI-EcoRI fragment containing the $1.5-\mathrm{kb}$ intron 1 and exons 2 and 3 of the human gastrin gene, which encodes the preprogastrin peptide precursor $(18,19)$. A 4.8-kb INSGAS fragment was isolated and microinjected into inbred FVB, one cell mouse embryos (20). (B) Gastrin immunoreactivity in pancreatic and stomach extracts from transgenic and nontransgenic mice assayed by radioimmunoassay using antisera 2604 (22) specific for the bioactive amidated $\mathrm{COOH}$ terminus of gastrin. Mean $\pm \mathrm{SE} ; n=4$ (C) Beta cell-specific gastrin expression from the INSGAS transgene. Immunostaining of pancreatic tissues with a gastrin monoclonal antibody.

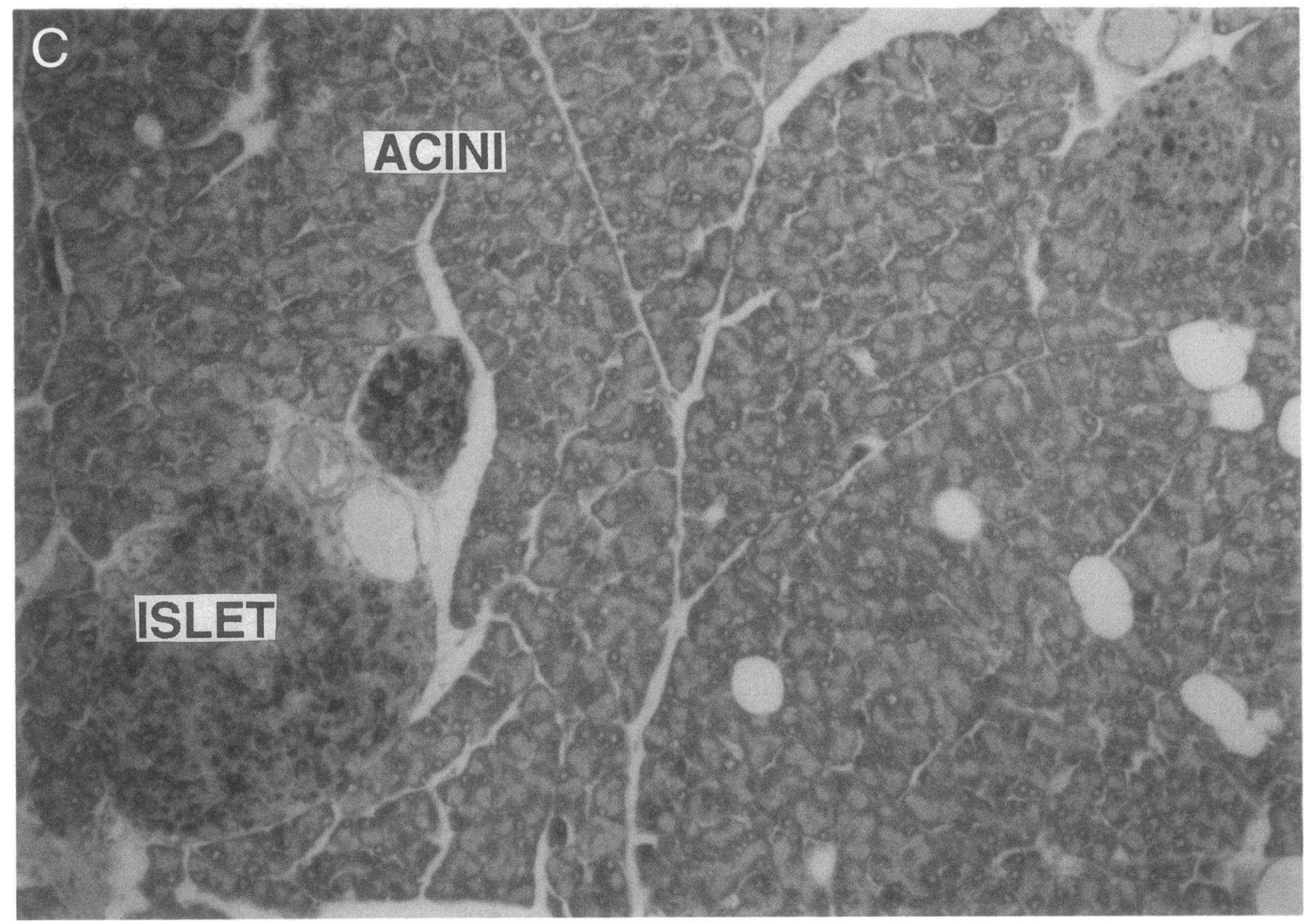

gastrin in the postnatal pancreas alone does not stimulate islet cell growth.

However, stimulation of islet growth by gastrin may require stimulation by other growth factors to create a responsive population of cells. Therefore, effects of gastrin stimulation were studied in TGF $\alpha$ transgenic mice which have metaplastic ducts that contain insulin-expressing cells resembling protodifferentiated islet precursors. To assess the interaction between gastrin and TGF $\alpha$, three groups of mice were bred with equivalent FVB/CD1 strain genetic backgrounds: nontransgenic control, TGF $\alpha$ single transgenic, and INSGAS/TGF $\alpha$ double transgenics. All three groups of mice were placed on $50 \mathrm{mM} \mathrm{ZnCl}$ at 3 
A

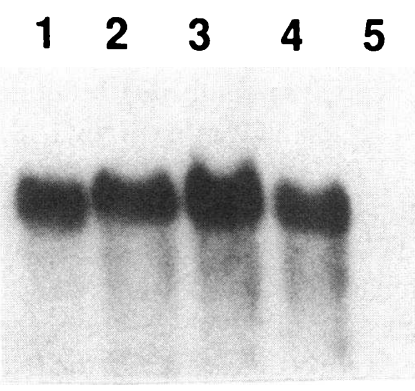

B

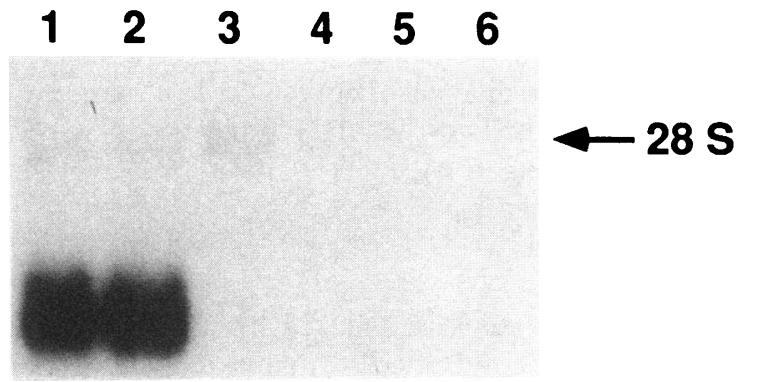

C

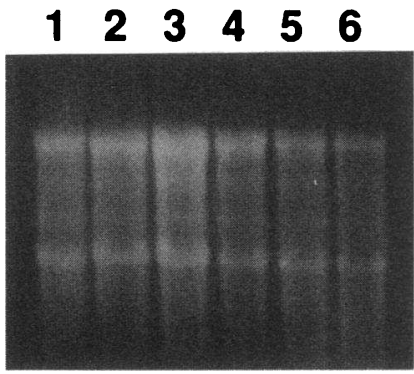

Figure 3. TGF $\alpha$ and gastrin gene expression in TGF $\alpha$ and INSGAS/ TGF $\alpha$ mice. Total RNA $(20 \mu \mathrm{g})$ was subjected to Northern blot analysis using ${ }^{32} \mathrm{P}$-labeled human gastrin and TGF $\alpha$ cRNA probes. ( $A$ ) Autoradiogram showing TGF $\alpha$ expression: lanes 1 and 2,

TGF $\alpha$ /INSGAS double transgenic mice; lanes 3 and 4, TGF $\alpha$ single transgenic mice; lanes 5 and 6 , control mice. $(B)$ Autoradiogram of the same blot showing gastrin expression. $(C)$ Ultraviolet photograph showing ethidium bromide staining of total RNA loading of the agarose gel used in the Northern blot shown in $A$ and $B$.

wk of age. At $17 \mathrm{wk}$ of age, the animals were killed and the pancreas removed for histological evaluation or analysis of TGF $\alpha$ and gastrin expression. TGF $\alpha$ expression was equivalent in TGF $\alpha$ and INSGAS/TGF $\alpha$ groups when measured by Northern blot analysis, whereas gastrin gene expression was

Figure 4. Light micrographs of hematoxylin-stained paraffin sections of pancreas from the three groups of mice studied: $(A)$ INSGAS/ TGF $\alpha$; $(B)$ FVB/CD1 controls; ( $C$ ) TGF $\alpha$. The INSGAS/TGF $\alpha$ pancreas $(A)$ had some areas of increased ductular complexes and slightly increased interstitial cellularity; the field shown here had the most severely abnormal morphology seen in the five animals; most of the pancreas was indistinguishable from controls $(B)$. In contrast, the field of TGF $\alpha$ pancreas $(C)$ was typical and showed the interstitial cellularity and fibrosis combined with florid ductular metaplasia described by Jhappan et al. (7). Magnification bar $=200 \mu \mathrm{m}$.
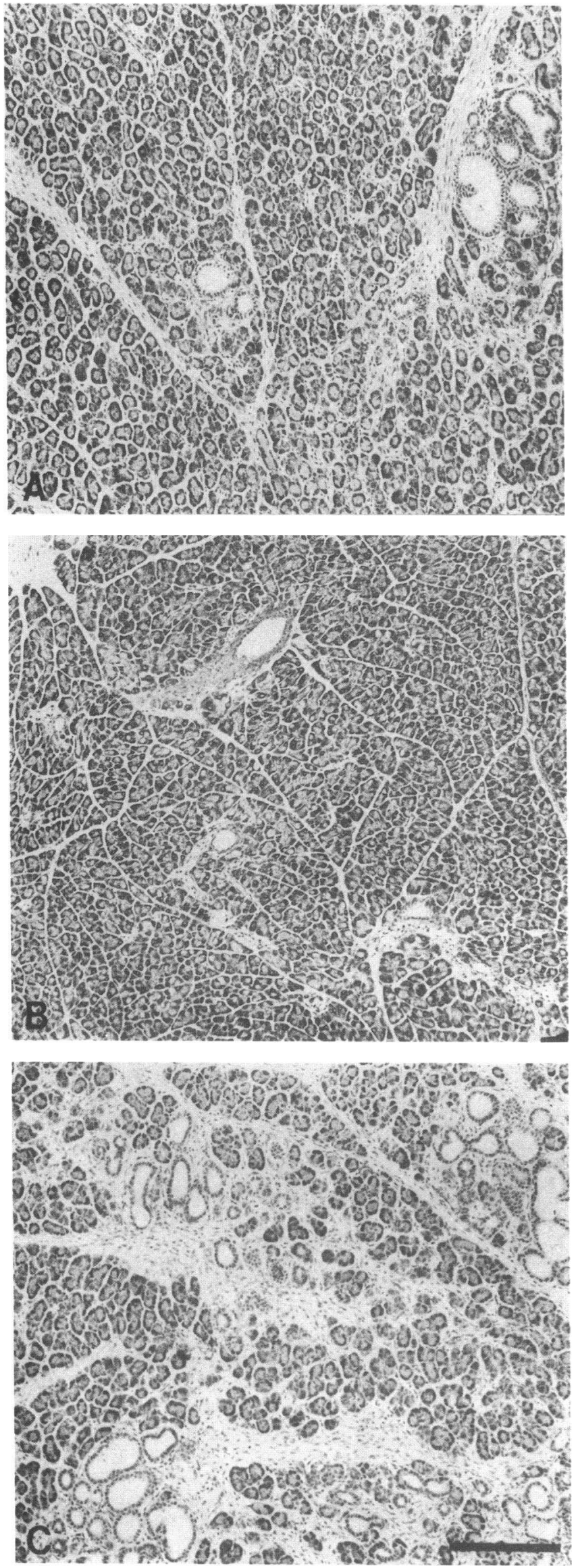

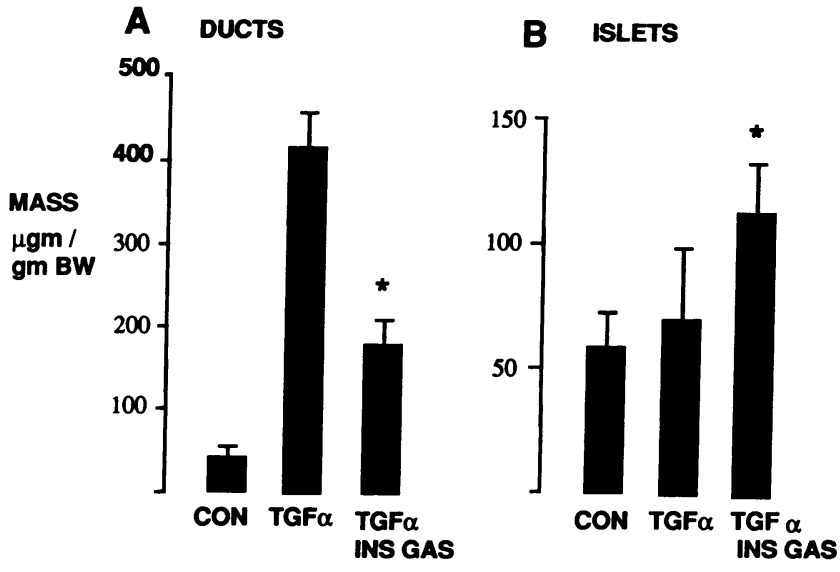

Figure 5. Pancreatic gastrin synergistically interacts with TGF $\alpha$ to increase islet mass and inhibit the ductular metaplasia induced by TGF $\alpha$ overexpression. Mating the homozygous MT-TGF $\alpha$ (MT-42) mice (TGF $\alpha$ ) with heterozygous INSGAS mice gave offspring that were either heterozygous TGF $\alpha$ single transgenic or double transgenic containing both INSGAS and TGF $\alpha$ transgenes (INSGAS/TGF $\alpha$ ). Relative volume of ducts $(A)$ and islets $(B)$ were quantified by pointcounting morphometrics as described in Methods. Mass of ductules or islet was calculated by multiplying the relative volume and the animal's pancreatic weight. To normalize different mean body weights, the mass was expressed as micrograms per gram body weight. Results are mean and standard errors for five to six animals in each group. $(A)$ *Significant difference between TGF $\alpha$ and INSGAS/TGF $\alpha . P$ $<0.05$ (Student's $t$ unpaired data). ( $B)^{*}$ Significant difference between CON and INSGAS/TGF $\alpha . P<0.05$ (Student's $t$ unpaired data).

only seen in the INSGAS/TGF $\alpha$ mice (Fig. 3). TGF $\alpha$ peptide immunoreactivity in pancreatic extracts measured by radioimmunoassay was $12.2 \pm 1$ and $18.9 \pm 8 \mathrm{ng} / \mathrm{mg}$ protein (mean \pm SD) in the TGF $\alpha$ and INSGAS/TGF $\alpha$ mice, respectively. Gastrin expression was only observed in INSGAS/ TGF $\alpha$ mice; no gastrin expression was detected in the FVB/ CD1 controls and the TGF $\alpha$ mice.

Expression of gastrin from the INSGAS transgene reduced the ductular proliferation and the interstitial fibrosis and cellularity caused by TGF $\alpha$ overexpression. At $17 \mathrm{wk}$, the pancre-

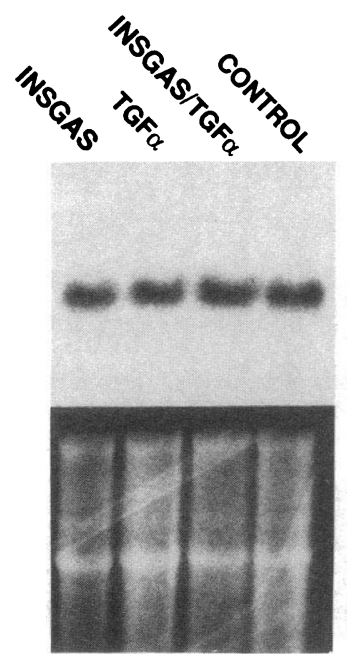

Figure 6. Comparison of insulin gene expression in pancreatic RNA from INGAS, TGF $\alpha$, and INSGAS/TGF $\alpha$ mice to insulin expression in agematched nontransgenic mice. Total pancreatic RNA ( $20 \mu \mathrm{g})$ was subjected to Northern blot analysis using a ${ }^{32} \mathrm{P}$ labeled rat gastrin $\mathrm{CRNA}$ probe. ( $U p$ per panel) Autoradiogram showing insulin mRNA expression: INSGAS and TGF $\alpha$ single transgenic mouse, TGF $\alpha$ /INSGAS double transgenic mouse, and nontransgenic control mice. (Lower panel) Ultraviolet photograph showing ethidium bromide staining of total RNA loading of the agarose gel used in the Northern blot shown above. atic histology of the INSGAS/TGF $\alpha$ mice (Fig. $4 A$ ) resembled that of the control pancreas (Fig. $4 B$ ) more than that of the TGF $\alpha$ mice (Fig. $4 C$ ). This was confirmed by quantifying pancreatic ductular mass in the TGF $\alpha$ and INSGAS/TGF $\alpha$ transgenic mice and the FVB1/CD1 controls by point-counting morphometrics (Fig. $5 \mathrm{~A}$ ). Coexpression of gastrin and TGF $\alpha$ in the INSGAS/TGF $\alpha$ pancreas also significantly increased the islet mass compared to controls, whereas islet mass was not increased by expression of the TGF $\alpha$ transgene alone although this was not significantly different from the INSGAS/ TGF $\alpha$ mice (Fig. $5 B$ ). Despite the increased islet mass in the INSGAS/TGF $\alpha$ mice, blood glucose concentrations were not significantly different between the three groups of mice. Furthermore, Northern blot analysis of pancreatic insulin mRNA levels showed no difference between the nontransgenic control mice and the INSGAS, the TGF $\alpha$ and the INSGAS/TGF $\alpha$ transgenic mice (Fig. 6).

\section{Discussion}

The ductular metaplasia induced by TGF $\alpha$ overexpression causes pancreatic ductal cells in adult mice to express genes normally restricted in the adult pancreas to islet or acinar cells. Sandgren et al. demonstrated amylase-positive cells within the metaplastic ductules ( 8$)$. The present study demonstrates numerous insulin staining cells in the TGF $\alpha$-induced metaplastic ductules. The low level of exocrine and endocrine gene expression in the metaplastic ductal cells resembles that of the protodifferentiated ductal cells postulated to occur in the early stage of fetal pancreatic development. However, it is not known whether these effects of TGF $\alpha$ overexpression in transgenic mice mimic the role of TGF $\alpha$ in the fetal pancreas. In the MT-42 (TGF $\alpha$ ) transgenic mice, the ductular metaplasia is not seen in the immediate postnatal period, but only after $8 \mathrm{wk}$ of age (Merlino, G. T., unpublished observations). Thus, TGF $\alpha$ overexpression induces insulin reexpression in duct epithelia, rather than prolonging the persistence of islet precursors found in fetal pancreatic ducts. Indeed the presence of cells containing both exocrine and mucin granules in the MT- 42 transgenic pancreas has prompted the hypothesis that TGF $\alpha$ causes the "redifferentiation" of acinar cells into cells with the phenotypic features of pancreatic ductal cells (9).

Expression of the gastrin transgene decreased the ductular metaplasia induced by TGF $\alpha$ overexpression. This may result from gastrin antagonizing the redifferentiation of acinar cells into ductal cells postulated to occur from acinar cell over expression of the TGF $\alpha$ transgene (9). Interactions between EGF and CCK, homologues of TGF $\alpha$ and gastrin, respectively, have been well studied on pancreatic exocrine cells. CCK decreases EGF receptor binding by stimulating intracellular $C$ kinase activity, which inhibits internalization of receptor bound EGF $(28,29)$. Although the metaplastic ductules contain numerous insulin-positive cells, the islet mass of the TGF $\alpha$ transgenic mice was not increased over controls. Thus, TGF $\alpha$ overexpression alone cannot effect transition of these insulin-expressing duct cells into fully differentiated islets. This implies that insufficient concentrations of other factors are present in the pancreas of adult TGF $\alpha$ transgenic mice to stimulate islet differentiation. Since differentiation of protodifferentiated islet precursors occurs during late fetal development, factors regulating this transition would likely be expressed in islets during this 
period. Among the factors expressed in the developing islets is the gastrointestinal peptide, gastrin. Clinical observations have also linked gastrin expression with nesidioblastosis, a histological appearance of islets budding from the pancreatic ducts ( 14 , 16). This resembles the formation of islets (neogenesis) from islet precursors found in ducts of the fetal pancreas.

The transgenic studies reported here support the hypothesis that gastrin stimulates islet growth, but only in the presence of other growth factors. Overexpression of gastrin alone in the postnatal pancreas of INSGAS transgenic mice did not increase islet growth, despite the high concentrations of bioactive gastrin being expressed within the pancreas. However, gastrin did increase adult islet mass in the presence of insulin-expressing ductular cells induced by TGF $\alpha$ overexpression. Since gastrin concomitantly decreased the metaplastic duct mass, the increased islet mass in the INSGAS/TGF $\alpha$ mice may result from gastrin inducing the differentiation of insulin positive cells in the TGF $\alpha$-induced metaplastic ductules. Alternatively, gastrin and TGF $\alpha$ may also act synergistically to promote islet neogenesis from undifferentiated stem cells or stimulate the growth of existing islets. In these actions, gastrin does not stimulate islet cell proliferation alone, but more likely promotes the growth and differentiation of islet precursors activated by other growth factors. This action of gastrin is consistent with the role of growth factors as regulators of cell differentiation as well as proliferation (30). Synergistic interactions between multiple growth factors are required to activate cellular differentiation programs, which comprise both proliferation and activation of cell specific gene expression.

Although both TGF $\alpha$ and gastrin are expressed in fetal pancreas, it is not known whether these peptides interact similarly to stimulate islet neogenesis during fetal development. Other factors also regulate islet growth both in fetal development and postnatally. Like gastrin, secretin and thyroid-releasing hormone are transiently expressed in the fetal islets and may also influence pancreatic development $(31,32)$, although there is no direct evidence for such a role. IGF-1 is also expressed in fetal islets and has been reported to stimulate replication of isolated islets in culture (33). Furthermore, IGF-1 expression is reactivated after pancreatectomy in foci of pancreatic regeneration (34).

Although the islets continue to grow after birth, the rate of islet replication decreases with age (35). Postnatal islet growth results largely from the replication of differentiated islet cells. In contrast to fetal life, islet neogenesis from protodifferentiated ductal precursors is not as significant a component of islet growth in the adult (36). In adult mammals, hyperglycemia and certain endocrine stimuli increase islet mass, largely by stimulating replication of preexisting islet cells (37). Nevertheless, islet neogenesis in the adult pancreas can be signifcantly enhanced in some conditions. There is substantial islet regeneration after pancreatectomy, both by replication of existing islets and by islet neogenesis (38). After $90 \%$ pancreatectomy, regenerative foci are seen containing pancreatic ducts which proliferate and differentiate into acinar and islet cells. Thus, pancreatic regeneration elicited by pancreatectomy recapitulates the program of islet neogenesis by reactivating latent acinar/islet precursors in the pancreatic ducts. However, it is not known which of the many growth factors released by tissue repair mediates postpancreatectomy islet neogenesis. The present transgenic study shows an increase in islet mass in adult mice can occur, without hyperglycemia or tissue loss as stimuli, through the pancreatic coexpression of two growth factors, gastrin and TGF $\alpha$.

\section{Acknowledgments}

We acknowledge the expert technical assistance of $R$. Schlesinger and C. J. Cahill, and thank Drs. John Walsh and Jens Rehfeld for antigastrin antibodies.

This research was supported by a Clinical Investigator Award from the National Institutes of Health (NIH) (DK01937) and a Juvenile Diabetes Foundation Research Grant (191671) to Timothy C. Wang. Susan Bonner-Weir was supported by an NIH grant (DK 44523) and a Juvenile Diabetes Foundation research grant (191905). Stephen J. Brand was supported by an NIH grant (DK 42147) and by a Juvenile Diabetes Foundation Career Development Award (289182).

\section{References}

1. Pictet, R., and W. Rutter. 1972. Development of the embryonic endocrine pancreas. In Endocrine Pancreas. D. F. Steiner and N. Freinkel, editors. American Physiological Society, Washington, DC. 25-66.

2. Teitelman, G., and J. K. Lee. 1987. Cell lineage of pancreatic islet cell development: glucagon and insulin cells arise from catecholaminergic precursors present in the pancreatic duct. Dev. Biol. 121:454-466.

3. Sporn, M. B., and A. B. Roberts. 1988. Peptide growth factors are multifunctional. Nature (Lond.). 332:217-219.

4. Levine, S., R. Pictet, and W. J. Rutter. 1973. Control of cell proliferation and cytodifferentiation by a factor reacting with the cell surface. Nature (New Biology). 246:49-51.

5. Verme, T. B., and S. R. Hootman. 1990. Regulation of pancreatic duct epithelial growth in vitro. Am. J. Physiol. 258:G833-G840.

6. Korc, M., B. Chandrasekar, Y. Yamanaka, H. Freiss, M. Buchler, and H. Beger. 1992. Overexpression of the epidermal growth factor receptor in human pancreatic cancer is associated with concomitant increases in the levels of epidermal growth factor and transforming growth factor alpha. J. Clin. Invest. 90:13521360 .

7. Jhappan, C., C. Stahle, R. N. Harkins, N. Fausto, G. H. Smith, and G. T. Merlino. 1990. TGF $\alpha$ Overexpression in transgenic mice induces liver neoplasia and abnormal development of the mammary gland and pancreas. Cell. 61:11371146.

8. Sandgren, E. P., N. C. Luettke, R. D. Palmiter, R. L. Brinster, and D. C. Lee. 1990. Overexpression of TGF $\alpha$ in transgenic mice: induction of epithelial hyperplasia, pancreatic metaplasia and carcinoma of the breast. Cell. 61:11211135.

9. Bockman, D. E., and G. Merlino. 1992. Cytological changes in the pancreas of transgenic mice overexpressing transforming growth factor $\alpha$. Gastroenterology. 103:1883-1892.

10. Logsdon, C. D., and J. A. Williams. 1983. Pancreatic acini in short-term culture: regulation by EGF, carbachol, insulin and corticosterone. Am. J. Physiol. 244:G675-G682.

11. Mainz, D. L., O. Black, and P. D. Webster. 1973. Hormonal control of pancreatic growth. J. Clin. Invest. 52:2300-2304.

12. Dembinski, A. B., and L. R. Johnson. 1980. Stimulation of pancreatic growth by secretin, caerulein, and pentagastrin. Endocrinology. 106:323-327.

13. Brand, S. J., and P. J. Fuller. 1988. Differential gastrin gene expression in rat gastrointestinal tract and pancreas during neonatal development. J. Biol. Chem. 263:5341-5347.

14. Sacchi, T. B., D. Bani, and G. Bilotti. 1985. Nesidioblastosis and islet changes related to endogenous hypergastrinema. Virchows Archiv B Cell Pathol. 48:261-276.

15. Heitz, P. U., G. Kloppel, W. H. Hacki, J. M. Polak, and A. G. Everson. 1977. Nesidioblastosis: the pathologic basis of persistent hyperinsulinemic hypoglycemia in infants. Diabetes. 26:632-642.

16. Hollande, E., B. Giron, T. Lehy, J. P. Accary, and C. Roze. 1976. In vitro secretion of gastrin, insulin, and glucagon in tissue cultures of pancreas from a child with neonatal intractable hypoglycemia. Gastroenterology. 71:255-262.

17. Cordell, B., G. Bell, E. Tischer, R. M. DeNoto, A. Ullrich, R. Pictet, W. J. Rutter, and H. M. Goodman. 1979. Isolation and characterization of a cloned rat insulin gene. Cell. 18:533-543.

18. Wiborg, O., L. Berglund, E. Boel, F. Norris, K. Norris, J. F. Rehfeld, K. A. Marcker, and J. Vuust. 1984. Structure of a human gastrin gene. Proc. Natl. Acad. Sci. USA. 81:1067-1069.

19. Ito, R., K. Sato, T. Helmer, G. Jay, and K. Agarwal. 1984. Structural 
analysis of the gene encoding human gastrin: the large intron contains an Alu sequence. Proc. Natl. Acad. Sci. USA. 81:4662-4666.

20. Hogan, B., F. Constantini, and E. Lacy. 1986. Manipulating the Mouse Embryo: A Laboratory Manual. Cold Spring Harbor Laboratory, Cold Spring Harbor, NY.

21. Cathala, G., J. F. Savouret, B. Mendez, B. L. West, M. Karin, J. A. Martial, and J. D. Baxter. 1983. A method for isolation of intact translationally active ribonucleic acid. DNA (NY). 2:329-335.

22. Stadil, F., and J. F. Rehfeld. 1972. Preparation of ${ }^{125}$ I-labeled synthetic human gastrin for radioimmunoanalysis. Scand. J. Clin. Lab. Invest. 30:361368.

23. Todaro, G. J., C. Fryling, and J. E. DeLarco. 1980. Transforming growth factors produced by certain human tumor cells: polypeptides that interact with epidermal growth factor receptors. Proc. Natl. Acad. Sci. USA. 77:5258-5262.

24. Sternberger, L. A. 1979. Immunocytochemistry. Wiley Liss, Inc., New York. 104-170.

25. Bonner-Weir, S., D. F. Trent, and G. C. Weir. 1983. Partial pancreatectomy in the rat and subsequent defect in glucose-induced insulin release. J. Clin. Invest. 71:1533-1544.

26. Weibel, E. R. 1963. Principles and methods for morphometric studies of the lung and other organs. Lab Invest. 12:131-155.

27. Alpert, S., D. Hanahan, and G. Teitelman. 1988. Hybrid insulin genes reveal a developmental lineage for pancreatic endocrine cells and imply a relationship with neurons. Cell. 53:295-308.

28. Korc, M., L. Matrisian, and B. E. Magun. 1984. Cytosolic calcium regulates epidermal growth factor endocytosis in rat pancreas and cultured fibroblasts. Proc. Natl. Acad. Sci. USA. 81:461-465.
29. Logsdon, C. D., and J. A. Williams. 1984. Intracellular $\mathrm{Ca}^{2+}$ and phorbol esters synergistically inhibit internalization of epidermal growth factor and pancreatic acini. Biochem. J. 223:893-900.

30. Metcalf, D. 1989. The molecular control of cell division, differentiation commitment and maturation in haemopoietic cells. Nature (Lond.). 339:27-30

31. Morley, J. E., T. J. Garvin, A. E. Pekary, and J. M. Hersham. 1977. Thyrotropin-releasing hormone in the gastrointestinal tract. Biochem. Biophys. Res. Commun. 79:314-318.

32. Wheeler, M. B., J. Nishitani, A. M. J. Buchan, A. S. Kopin, W. Y. Chey, T.-M. Chang, and A. B. Leiter. 1992. Identification of a transcriptional enhancer important for enteroendocrine and pancreatic islet cell-specific expression of the secretin gene. Mol. Cell. Biol. 12:3531-3539.

33. Romanus, J. A., A. Rabinovitch, and M. M. Rechler. 1985. Neonatal rat islet cell cultures synthesize insulin-like growth factor I. Diabetes. 34:696-702.

34. Smith, F. E., K. M. Rosen, L. Villa-Komaroff, G. C. Weir, and S. BonnerWeir. 1991. Enhanced insulin-like growth factor I gene expression in regenerating rat pancreas. Proc. Natl. Acad. Sci. USA. 88:6152-6156.

35. Swenne, I. 1983. Effects of aging on the regenerative capacity of the pancreatic B-cell of the rat. Diabetes. 32:14-19.

36. Hellerstrom, C., I. Swenne, and A. Andersson. 1988. In The Pathology of the Endocrine Pancreas. P. J. Lefebvre and D. G. Pipeleers, editors. Springer-Verlag, Heidelberg. 141-170.

37. Logenthopoulos, J. 1972. Islet regeneration and neogenesis. In Endocrine Pancreas. D. F. Steiner and N. Freinkel, editors. American Physiological Society, Washington, DC. 67-76.

38. Bonner-Weir, S., L. A. Baxter, P. Schuppin, and F. E. Smith. 1991. Two pathways for beta cell regeneration after $90 \%$ pancreatectomy. Diabetes. 40:163A. (Abstr.) 